\title{
THE ROMANCE OF
}

\section{BLONDE OF OXFORD AND JEHAN OF DAMMARTIN.}

BÝ PHILIPPE DE REIMES,

A TROUVÈRE OF THE THIRTEENTH CENTURY.

EDITED,

EROM THE UNIQUE MS. IN THE IMPERIAL LIBRARY IN PARIS, BY M. LE ROUX DE LINCY.

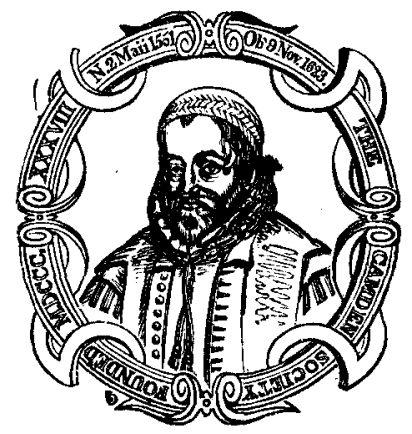

PRIN'TED FOR THE CAMDEN SOCIETY.

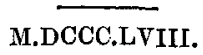


WESTMINSTER :

J. B, NICHOLS AND SONS, PRINTERS, Parliament streEt.

[LXXII.] 


\title{
COUNCIL OF THE CAMDEN SOCIETY
}

FOR THE YEAR 1858-9.

\author{
President, \\ THE EARL JERMYN, M.P. F.S.A. \\ WILLIAM HENRY BLAAUW, ESQ. M.A., F.S.A. \\ JOHN BRUCE, ESQ. V.P.S.A. Director. \\ JOHN PAYNE COLLIER, ESQ. F.S.A. Treasurer. \\ WILLIAM DURRANT COOPER, ESQ. F.S.A. \\ BOLTON CORNEY, ESQ. M.R.S.L. \\ JAMES CROSBY, ESQ. F.S.A. \\ JOHN FORSTER, ESQ. \\ EDWARD FOSS, ESQ. F.S.A. \\ THOMAS W. KING, ESQ. F.S.A., York Herald. \\ THE REV. LAMBERT B. LARKING, M.A. \\ PETER LEVESQUE, ESQ. F.S.A. \\ SIR FREDERICK MADDEN, K.H., F.R.S. \\ FREDERIC OUVRY, ESQ. Treas.S.A. \\ WILLIAM J. THOMS, ESQ. F.S.A. Secretary. \\ WILLIAM TITE, ESQ. M.P. F.R.S. F.S.A.
}


The Council of the CAmpen Soctetr desire it to be understood that they are not answerable for any opinions or observations that may appear in the Society's publications; the Editors of the several works being alone responsible for the same. 